\title{
Identification of Glucagon in the Gastrointestinal Tract
}

\author{
Hideo Sasaki, Boanerges Rubalcava, Dany Baetens, \\ Enrique Blazquez, C. B. Srikant, Lelio Orci, and Roger H. Unger \\ From the Veterans Administration Hospital and the Department of Internal \\ Medicine, The University of Texas Southwestern Medical School at Dallas, \\ Dallas, Texas 75235, and l'Institut d'Histologie et Embryologie, Université de \\ Geneve, Geneva, Switzerland
}

A B S T R A C T Gel filtration studies on Bio-Gel P-10 columns of a 50 -fold purified porcine duodenal extract revealed a main peak of glucagon-like immunoreactivity (GLI) in the $2,900 \mathrm{~mol}$ wt zone and a smaller peak in the $3,500 \mathrm{~mol}$ wt zone, the same zone as the pancreatic glucagon marker. Like pancreatic glucagon, samples of $3,500 \mathrm{~mol}$ wt material gave essentially identical measurements in radioimmunoassays employing the pancreatic glucagon-specific antiserum $30 \mathrm{~K}$ and the GLI crossreacting antiserum $78 \mathrm{~J}$, whereas the $2,900 \mathrm{~mol} \mathrm{wt}$ peptide gave 60 -fold higher readings in the $78 \mathrm{~J}$ assay. On disk gel electrophoresis, the $3,500 \mathrm{~mol}$ wt fraction, like pancreatic glucagon, migrated at $\mathrm{pH} 8.3$, whereas the $2,900 \mathrm{~mol}$ wt peptide remained at the origin; at $\mathrm{pH}$ 4.7 , the 2,900 mol wt peptide migrated while the 3,500 mol wt immunoreactive peptide and glucagon remained at the origin. Isoelectric focusing revealed the 3,500 mol wt moiety to have an isoelectric point ( $\mathrm{pI}$ ) of 6.2 , the same as pancreatic glucagon, whereas the 2,900 mol wt peptide had an $\mathrm{pI}>10$. The glycogenolytic activity of the $3,500 \mathrm{~mol}$ wt peptide in the perfused rat liver did not differ significantly from glucagon, and its adenylate cyclase stimulating activity in partially purified liver cell membranes was comparable to that of glucagon; the 2,900 mol wt peptide had less than $20 \%$ of these activities. In samples of $3,500 \mathrm{~mol} w t$ material subjected to isoelectric focusing, adenylate cyclase-stimulating activity was confined to fractions containing $30 \mathrm{~K}$ immunoreactivity with a pI of 6.2. In samples of 2,900 mol wt material subjected to isoelectric focusing,

Dr. Sasaki's present address is The First Department of Internal Medicine, Niigata University School of Medicine, Niigata, Japan. Dr. Rubalcava's present address is The Departamento de Bioquímica, Centro de Investigacion y Estudios Avanzados del Instituto Politecnico Nacional, Mexico, D.F.

Received for publication 11 October 1974 and in revised form 11 March 1975. adenylate cyclase-stimulating activity was confined to fractions containing $78 \mathrm{~J}$ immunoreactivity with an pI $>10$. Displacement of $\left[{ }^{125} \mathrm{I}\right]$ glucagon from the membranes was limited to these two biologically active fractions. However, the affinity of both pancreatic glucagon and the $3,500 \mathrm{~mol}$ wt peptide was an order of magnitude greater than that of the $2,900 \mathrm{~mol}$ wt peptide. Thus, by all of several biologic, physicochemical, and immunometric techniques, the 3,500 mol wt gut immunoreactive peptide could not be distinguished from pancreatic glucagon, while the $2,900 \mathrm{~mol}$ wt peptide was readily differentiated by all these techniques. "True" A-cells, ultrastructurally indistinguishable from pancreatic A-cells but differing from the A-like cells of the lower bowel, were identified in the gastric fundus of dogs. Their distribution corresponded to that of the $3,500 \mathrm{~mol} w \mathrm{wt}$ immunoreactivity resembling pancreatic glucagon, while the distribution of "A-like cells" in the lower small intestine corresponded to that of GLI.

\section{INTRODUCTION}

It has recently been reported by Vranic, Pek, and Kawamori (1), Matsuyama and Foa (2), and Mashiter et al. (3) that the plasma of totally depancreatized dogs contains normal or increased quantities of a material immunometrically indistinguishable from pancreatic glucagon by radioimmunoassays regarded as highly specific for pancreatic glucagon. This postpancreatectomy immunoreactivity could not be attributed to cross-reaction with high levels of gut glucagon-like immunoreactivity $\left(\mathrm{GLI}^{1}\right)$ (4), a group of immunometrically dissimilar polypeptides which is not elevated after pancreatectomy (5). Moreover, after total pancreatectomy, the responses

\footnotetext{
${ }^{1}$ Abbreviations used in this paper: CMC, carboxymethyl cellulose; GLI, glucagon-like immunoreactivity; $\mathrm{K}_{\mathrm{av}}$, partition coefficient; pI, isoelectric point.
} 
of glucagon to arginine $(1,3,5)$ and insulin (5) mimic the responses of pancreatic glucagon rather than those of gut GLI, thus raising the possibility that a polypeptide immunometrically indistinguishable from pancreatic glucagon may originate from extrapancreatic tissues.

These studies were designed to determine if a polypeptide indistinguishable by available methodology from pancreatic glucagon, but previously obscured by and confused with larger amounts of GLI, might be present in extracts of gastrointestinal tissues and, if so, whether a true A-cell could be identified outside the pancreas and differentiated from the "A-like cells" of postduodenal small intestine (6), considered to be the source of GLI (7).

\section{METHODS}

The starting material, an extract of pork duodenum purifiea 50-fold by Professor Viktor Mutt (8), Karolinska Institutet, Stockholm, was subjected to gel filtration on Bio-Gel P-10 columns (Bio-Gel, Bio-Rad Laboratories, Richmond, Calif.) $(0.9 \times 115 \mathrm{~cm})$ using $50 \mathrm{mM}$ ammonium bicarbonate buffer $(\mathrm{pH} 8.8)$ at a flow rate of $6 \mathrm{ml}$ per h at $4^{\circ} \mathrm{C}$. Each $1.4-\mathrm{ml}$ fraction was collected and frozen immediately until analyzed. Blue dextran 2,000, human growth hormone cytochrome $\mathrm{C},{ }^{125} \mathrm{I}$-labeled and unlabeled insulin and glucagon, and vasopressin were used as molecular weight markers. Molecular weights were estimated by the formula:

$$
K_{\mathrm{av}}=\frac{V_{e}-V_{o}}{V_{t}-V_{o}}
$$

where $K_{\mathrm{av}}$ is the partition coefficient, $V_{e}$ the elution volume of the peptide, $V_{o}$ the void volume, and $V_{t}$ the total elution volume.

For further studies requiring larger quantities of material, 1-2 $\mathrm{g}$ of sample was applied to Bio-Gel P-10 columns $(5 \times 115 \mathrm{~cm})$, and fractions corresponding to those of the smaller column were pooled and lyophilized.

GLI was measured in each fraction by radioimmunoassay (9) using antiserum 78J from a rabbit immunized against beef-pork glucagon. This antiserum cross-reacts strongly with GLI. "Pancreatic glucagon" immunoreactivity was measured with antiglucagon serum from rabbit $30 \mathrm{~K}$. This antiserum is highly specific for pancreatic glucagon in that it measures less than $3 \%$ of the $78 \mathrm{~J}$ immunoreactivity present in crude or 500-fold purified acid alcohol extracts of gut. Moreover, it does not react at all with secretin, pancreozymin, GIP, or VIP. Insulin levels were measured in 13 of the extracts by the method of Yalow and Berson (10), as modified by Herbert, Lau, Gottlieb, and Bleicher (11) for the purpose of excluding contamination of the duodenal extracts by pancreatic tissue.

The immunoreactive fractions were further purified by ion exchange column chromatography using a cation exchange resin, carboxymethyl cellulose (CMC), (Serva, Gallard-Schlesinger Chemical Manufacturing Corp., Carle Place, N. Y.) activated by ordinary cyclic washing with 0.2 $\mathrm{M} \mathrm{NaOH}$ and $0.2 \mathrm{M} \mathrm{HCl}$ and equilibrated in $10 \mathrm{mM}$ ammonium acetate buffer $(\mathrm{pH} 3.7)$ in $1.5 \times 15 \mathrm{~cm}$-siliconized columns. After application of samples, the columns were washed with $100 \mathrm{ml}$ of the above buffer and eluted with $300 \mathrm{ml}$ of solution consisting of a linear gradient of $\mathrm{KCl}, 0 \mathrm{M}-0.5 \mathrm{M}$ in
$10 \mathrm{mM}$ ammonium acetate buffer, $\mathrm{pH} 3.7$, followed by 100 $\mathrm{ml}$ of $2 \mathrm{M} \mathrm{KCl}$, the same buffer, at a flow rate of $30 \mathrm{ml}$ per $h$ at $4^{\circ} \mathrm{C}$. The eluate was collected in 5-ml fractions, and immunoreactive fractions were pooled and lyophilized for further purification.

The purified immunoreactive fractions were subjected to disk gel electrophoresis in $10 \%$ acrylamide gel in alkaline ( $\mathrm{pH}$ 8.3) (12) and in acid buffers ( $\mathrm{pH} \mathrm{4.7)} \mathrm{(13).} \mathrm{Brom-}$ phenol blue and pyronin $\mathrm{Y}$ were used as indicators. The gel was divided into $1.5-\mathrm{mm}$ slices by a Bio-Rad (Bio-Rad Laboratories, Richmond, Calif.) slicer. Groups of three slices were combined for extraction with $2 \mathrm{ml}$ of assay diluent by microhomogenization. The homogenates were centrifuged for $10 \mathrm{~min}$ at $2,000 \mathrm{rpm}$, and the supernates were assayed for immunoreactivity.

Isoelectrofocusing column chromatography was carried out with an LKB 8,101 110-ml electrofocusing column (LKB Instruments, Inc., Rockville, Md.). $1 \%$ ampholine was employed as the ampholite, $\mathrm{pH} 5-10$. A solution containing $1.5 \%$ ethylenediamine and $47 \%$ sucrose was used for the cathode at the bottom. A solution of $1 \%$ phosphoric acid was used for the anode at the top. A sucrose gradient ranging from 47 to $0 \%$ was made manually. $2 \mathrm{ml}$ of sample solution was applied to the middle of the column. The anolyte was layered above the formed gradient. The run was carried out at $4^{\circ} \mathrm{C}$ for $48 \mathrm{~h}$ at $300 \mathrm{~V}$. The column was eluted by gravity flow. Each 1.6-ml fraction was collected for measurement of $\mathrm{pH}$, absorbance at $280 \mathrm{~nm}$, and immunoreactivity.

Glycogenolytic activity of the fractions was estimated from glucose production by the isolated rat liver preparation of Mortimore (14). Glucose concentration in the perfusate was determined by the glucose oxidase method using the Technicon Autoanalyzer (Technicon Instrument Corp., Tarrytown, N. Y.).

Adenylate cyclase activity was determined by the method of Solomon, Londos, and Rodbell (15) in isolated rat liver cell membranes prepared by the method of Neville (16). [ $\left.{ }^{125} \mathrm{I}\right]$ glucagon binding to liver cell membranes was determined as described by Rubalcava and Rodbell (17).

Gastrointestinal tissues were obtained from dogs subjected to laparotomy under nembutal anesthesia. After sections of tissue had been removed for morphologic studies, the animals were sacrificed with an overdose of nembutal and the gut removed. The mucosa was scraped away and frozen in dry ice and stored at $-20^{\circ} \mathrm{C}$ until the time of extraction. Extracts were prepared by the method of Kenny (18) and were subsequently assayed for glucagon and GLI.

The tissue slices were diced into small cubes in $4 \%$ glutaraldehyde solution in phosphate buffer $(0.1 \mathrm{M}, \mathrm{pH}$ 7.4 ), postfixed in $2 \%$ osmium tetroxide for $2 \mathrm{~h}$, dehydrated in ethanol, and embedded in Epon 812 (Epon Adhesive Synthetic Resin, Shell Chemical Co., N. Y.) (19). Sections $600-800 \AA$ thick were cut with a diamond knife and stained with uranylacetate and lead citrate (20). Electron micrographs were recorded on 70-mm film in a Philips EM 300 electron microscope (Philips Electronic Instruments, Mount Vernon, N. Y.).

\section{RESULTS}

Molecular weight estimation of gut immunoreactivities in porcine duodenal extracts of Mutt. Eluates of porcine duodenal extracts from the Bio-Gel P-10 column, when measured with the highly cross-reactive antibody 
$78 \mathrm{~J}$, contained a main peak of immunoreactivity that followed the $\left[{ }^{125} \mathrm{I}\right]$ glucagon marker. A smaller peak of immunoreactivity corresponding to the $3,500 \mathrm{~mol} \mathrm{wt}$ glucagon marker was also uniformly noted in such extracts. Rechromatography of the eluates from the P-10 column revealed persistence of this biphasic pattern of immunoreactivity (Fig. 1). The two peaks of immunoreactivity in the $3,500 \mathrm{~mol} \mathrm{wt}$ and $2,900 \mathrm{~mol} \mathrm{wt}$ zones were also noted when the eluates were assayed with antiserum $30 \mathrm{~K}$ (Fig. 1).

The $K_{\mathrm{av}}$ of the larger molecular weight fraction was $0.56 \pm 0.02$, the same as pancreatic glucagon, and it was estimated to have an mol wt of approximately 3,500. Its $K_{\mathrm{ar}}$ was significantly less than that of the large peak, which was $0.641 \pm 0.01 \quad(P<0.001)$ (Fig. 2), corresponding to a weight of approximately 2,900 .

Immunometric comparison of 2,900 and 3,500 mol wet fractions. Pancreatic glucagon gives identical measurements when assayed with antiglucagon sera of varying specificity, whereas gut GLI gives widely divergent readings. To determine if the material in the $3,500 \mathrm{~mol}$

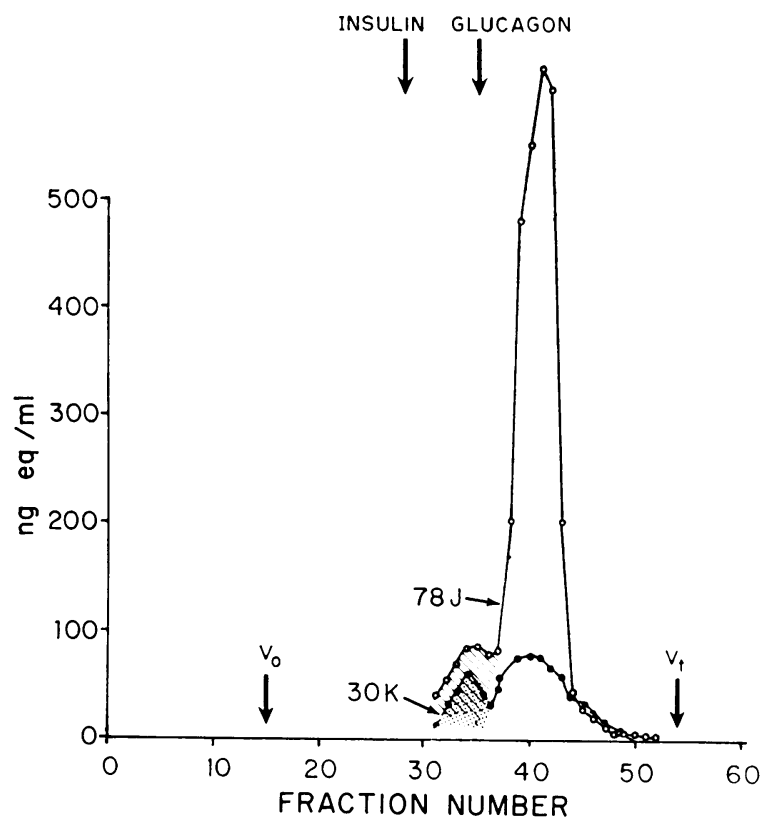

Figure 1 Elution pattern of $30 \mathrm{~K}$ specific (-๑) and $78 \mathrm{~J}$ cross-reacting $(\mathrm{O}-\mathrm{O})$ immunoreactivity of porcine duodenal extract on rechromatography on Bio-Gel P-10 column (50-100 mesh) $(0.9 \mathrm{~cm} \times 115 \mathrm{~cm})$ showing two peaks of immunoreactivity with each antiserum. Each fraction measured $1.4 \mathrm{ml}$. One peak corresponds to the glucagon marker of about $3,500 \mathrm{~mol}$ wt while a larger peak appearing later is estimated to have a mol wt of 2,900 ; the latter is far more reactive with $78 \mathrm{~J}$ than with $30 \mathrm{~K}$. Calculations of $78 \mathrm{~J} / 30 \mathrm{~K}$ ratios of $3,500 \mathrm{~mol} \mathrm{wt}$. Immunoreactive peaks are based on the ratios of the crosshatched area of $78 \mathrm{~J}$ immunoreactivity and the stippled area of $30 \mathrm{~K}$ immunoreactivity from which trailing of $2,900 \mathrm{~mol}$ wt immunoreactivity peaks has been subtracted.

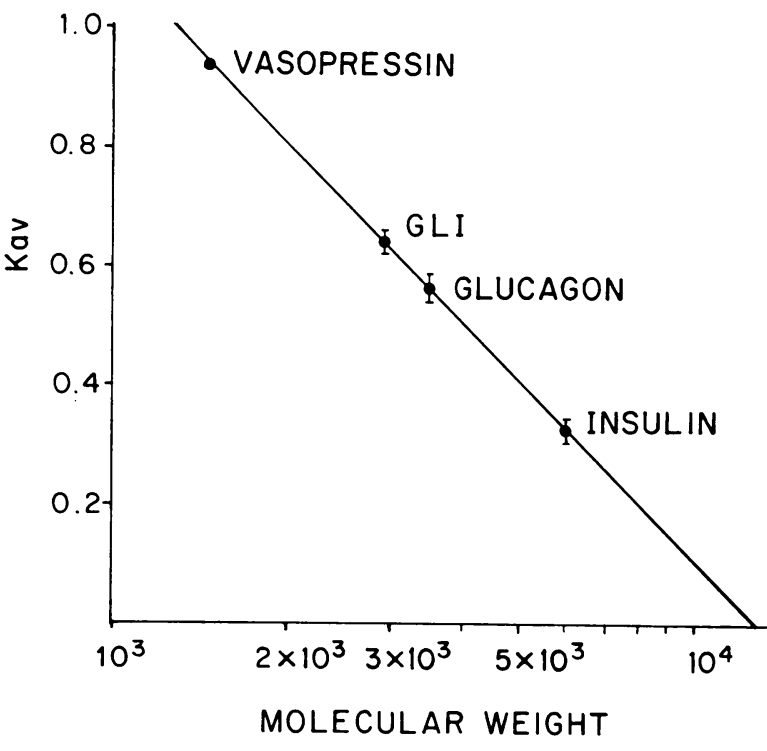

Figure 2 Estimation of molecular weights of the immunoreactive peptides by chromatography on Bio-Gel P-10 (the vertical lines represent mean $\pm S E M)$. The fractions contained, in addition to the immunoreactive peptides, ${ }^{125} \mathrm{I}$ labeled and unlabeled insulin, glucagon, and vasopressin as molecular weight markers.

wt zones was immunometrically similar to pancreatic glucagon, the ratio of measurements made with the cross-reacting antiserum 78J and the "glucagon-specific" antibody $30 \mathrm{~K}$ was calculated for each eluate. In the chromatogram shown in Fig. 1, the ratio of $78 \mathrm{~J}$ to $30 \mathrm{~K}$ immunoreactivity is much higher for the $2,900 \mathrm{~mol} \mathrm{wt}$ fraction than for the $3,500 \mathrm{~mol}$ wt fraction. In six separate experiments employing the more highly purified preparations after CMC chromatography, the immunometric ratios in the $3,500 \mathrm{~mol}$ wt zone averaged $0.9 \pm$ 0.13 (SD) after correction for the presence of "tailing" of the 2,900 mol wt GLI material into the $3,500 \mathrm{~mol} \mathrm{wt}$ zone. This involved subtracting from the total $78 \mathrm{~J} \mathrm{im-}$ munoreactivity the immunoreactivity beneath an extrapolated extension of the lines of the $2,900 \mathrm{~mol}$ wt peak to the base line, the ratio of $78 \mathrm{~J}$ to $30 \mathrm{~K}$ immunoreactivity for the $3,500 \mathrm{~mol} w \mathrm{wt}$ fraction (crosshatched area of $78 \mathrm{~J}$ immunoreactivity divided by the stipled area of $30 \mathrm{~K}$ immunoreactivity, as illustrated in Fig. 1). This is about the same $78 \mathrm{~J} / 30 \mathrm{~K}$ ratio as pancreatic glucagon (Table I). By contrast, the $78 \mathrm{~J}$ to $30 \mathrm{~K}$ immunoreactivity ratio for the $2,900 \mathrm{~mol}$ wt peak was $28.1 \pm 7.3$ in the starting material (Mutt extract [8]) and $61.1 \pm 22.6$ after desalting of the fraction purified by CMC chromatography.

These findings suggest that the $3,500 \mathrm{~mol} w t$ fraction is immunometrically indistinguishable from pancreatic glucagon with these two antisera while the $2,900 \mathrm{~mol} \mathrm{wt}$ fraction differs sharply. 
TABLE I

Comparison of Radioimmunoassay Values for the 3,500 and 2,900 mol wt Components of Partially Purified Porcine Duodenal Extract Measured with Cross-Reactive $(78 \mathrm{~J})$ and Relatively Specific (30K) Antisera

\begin{tabular}{lccc}
\hline & $\begin{array}{c}\text { Mean } \\
\text { 78J value }\end{array}$ & $\begin{array}{c}\text { Mean } \\
\text { 30K value }\end{array}$ & $\begin{array}{c}\text { Mean } \\
78 \mathrm{~J} / 30 \mathrm{~K} \text { ratio }\end{array}$ \\
\hline & $\pm S D$ & $\pm S D$ & $\pm S D$ \\
$3,500 \mathrm{~mol}$ wt immunoreactivity, ng eq $/ \mathrm{ml}^{*}$ & $6.1 \pm 0.4$ & $7.0 \pm 0.3$ & $0.9 \pm 0.13$ \\
2,900 mol wt immunoreactivity, ng eq/ $\mathrm{ml}^{*}$ & $4,450 \pm 106$ & $72.8 \pm 26.9$ & $61.1 \pm 22.6$ \\
\hline
\end{tabular}

$* n=6$.

Disk gel electrophoresis of the 3,500 mol wt and 2,900 mol wt fractions. To compare its net charge with pancreatic glucagon, the $3,500 \mathrm{~mol}$ wt fraction was subjected to disk gel electrophoresis. At $\mathrm{pH} 8.3$ (Tris- $\mathrm{HCl}$ buffer, $\mu=0.05$ ), the $3,500 \mathrm{~mol}$ wt $30 \mathrm{~K}$ immunoreactive peptide, like pancreatic glucagon, migrated to the midportion of the gel while the $2,900 \mathrm{~mol} \mathrm{wt} 78 \mathrm{~J}$ immunoreactive peptide remained at the origin (Fig. 3). At $\mathrm{pH} 4.7$ (acetate buffer, $\mu=0.05$ ), the $3,500 \mathrm{~mol} \mathrm{wt}$ immunoreactive peptide, like pancreatic glucagon, migrated only slightly, whereas the $2,900 \mathrm{~mol}$ wt peptide migrated more rapidly (Fig. 3 ). The $3,500 \mathrm{~mol} w \mathrm{w}$ fraction appears to resemble pancreatic glucagon and to differ from the strongly basic 2,900 mol wt GLI with respect to net charge.
Isoelectric focusing column chromatography of the 3,500 mol wt and 2,900 mol wt fractions. To determine their isoelectric points (pI), both the $3,500 \mathrm{~mol} \mathrm{wt}$ and the $2,900 \mathrm{~mol}$ wt fractions were subjected to isoelectric focusing column chromatography, and the various fractions were then assayed with both antiserum $78 \mathrm{~J}$ and antiserum $30 \mathrm{~K}$. In both assays, the major peak of immunoreactivity of the $3,500 \mathrm{~mol}$ wt fraction was noted at $\mathrm{pH}$ 6.2, the $\mathrm{pI}$ of glucagon in this system (Fig. 4) (Bromer has reported the pI of porcine glucagon to be near $\mathrm{pH} 7.0$ [21]). Like pancreatic glucagon, this peak has a $78 \mathrm{~J} / 30 \mathrm{~K}$ ratio of approximately one (Fig. 4). Another peak of $78 \mathrm{~J}$ immunoreactivity had a pI of more than 10 and a $78 \mathrm{~J} / 30 \mathrm{~K}$ ratio of about eight and may represent contaminating $2,900 \mathrm{~mol}$ wt glucagon-like im-

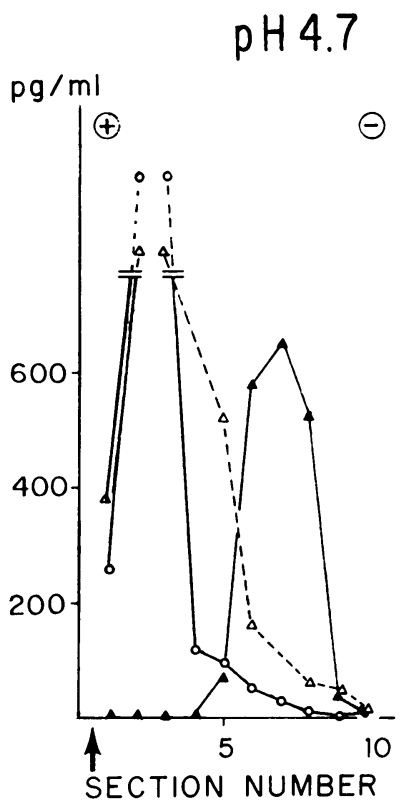

pH 8.3

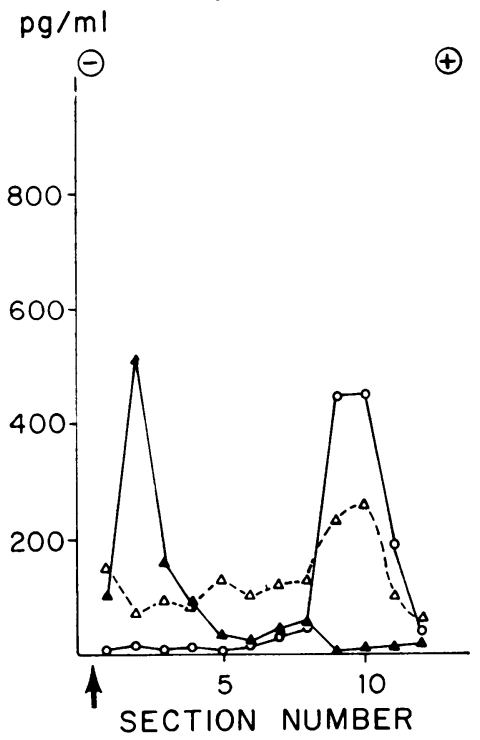

Figure 3 Polyacrylamide gel disk electrophoresis of pancreatic glucagon $(\bigcirc-\bigcirc)$ showing glucagon immunoreactivity in $\mathrm{pg} / \mathrm{ml}$ for the $3,500 \mathrm{~mol}$ wt immunoreactive peptide measured with antiserum $30 \mathrm{~K}(\triangle-\triangle)$ and for the $2,900 \mathrm{~mol}$ wt peptide $(\boldsymbol{\Delta}-\mathbf{\Delta})$ measured with antiserum $78 \mathrm{~J}$. The immunoreactivities were measured in $4.5-\mathrm{mm}$ sections of the gel. Arrows indicate the origin. 

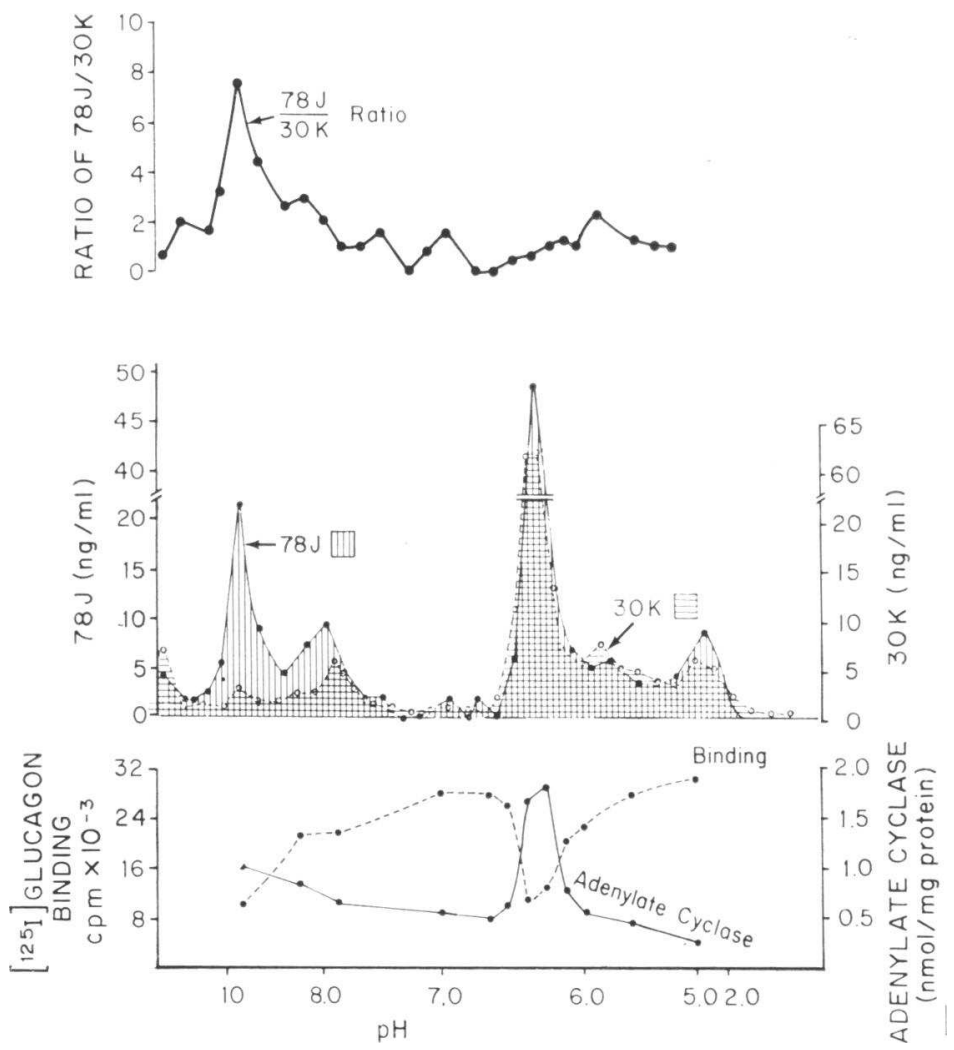

FIGURE 4 Isoelectric focusing column chromatography of the $3,500 \mathrm{~mol}$ wt peak. Conventional plotting of $\mathrm{pH}$ gradient has been omitted and instead $\mathrm{pH}$ is displayed at the appropriate points on the horizontal axis in lieu of the fraction numbers. Upper panel is the immunometric ratio of each fraction; middle panel is the immunoreactivity determined with $30 \mathrm{~K}$ and $78 \mathrm{~J}$; and the lower panel is adenylate cyclase stimulating activity expressed in nmoles of cyclic AMP formed per milligram rat liver membrane protein and $\left.{ }^{125} \mathrm{I}\right]$ glucagon displacement.

munoreactivity which has a pI of more than 10 (Fig. 5 ). $30 \mathrm{~K}$ immunoreactivity with an $\mathrm{pI}$ over 10 is thought to represent cross-reaction with this moiety.

Isoelectric focusing column chromatography of fractions containing the $2,900 \mathrm{~mol} \mathrm{wt}$ immunoreactivity revealed the $78 \mathrm{~J}$ immunoreactivity to be concentrated at $\mathrm{pH} 10.1$, with a smaller peak at 8.8 (Fig. 5). Thus, the GLI peptide had a pI over 10 in this system. $30 \mathrm{~K}$ immunoreactivity was more widely distributed, a substantial quantity coinciding with $78 \mathrm{~J}$ immunoreactivity and suggesting cross-reactivity. Additional peaks with much lower $78 \mathrm{~J} / 30 \mathrm{~K}$ ratios were observed in the lower $\mathrm{pH}$ zone and suggested the presence of other polypeptides more closely related to pancreatic glucagon.

Effect of the 3,500 mol wt and 2,900 mol wt fractions on adenylate cyclase activity and $\left[{ }^{125} \mathrm{I}\right]$ glucagon displacement in liver membranes. The $3,500 \mathrm{~mol} \mathrm{wt}$ fraction was compared with pancreatic glucagon with respect to its ability to activate adenylate cyclase in partially purified rat liver membranes. As shown in Fig. 6, the adenylate cyclase activity generated by the $3,500 \mathrm{~mol} \mathrm{wt}$ fraction was close to the dose response curve for glucagon, while considerably larger quantities of the 2,900 mol wt fraction were required to achieve the same level of activity. For example, $3078 \mathrm{~J} \mathrm{ng} \mathrm{eq} \mathrm{of} \mathrm{GLI} \mathrm{were}$ required to activate adenylate cyclase to a level comparable to that produced by $3.5 \mathrm{ng}$ of pancreatic glucagon. $3078 \mathrm{~J} \mathrm{ng} \mathrm{eq} \mathrm{measure} \mathrm{only} 0.5 \mathrm{ng}$ in the $30 \mathrm{~K}$ assay, less than the amount of pancreatic glucagon required to significantly increase adenylate cyclase activity. This excludes adenylate cyclase activation by a peptide resembling pancreatic glucagon and indicates that the activity must be due either to the GLI itself or to a biologically active material that does not react with $30 \mathrm{~K}$, such as VIP, ${ }^{2}$ or both.

Evidence that the immunoreactivities, rather than nonimmunoreactive materials in the various fractions,

${ }^{2}$ Radioimmunoassay and bioassay of VIP in these eluates, performed by Dr. Sami Said's laboratory at the Veterans Administration Hospital, Dallas, Texas, revealed a concentration below $10^{-9} \mathrm{M}$ which is far less than the minimum stimulatory concentration of adenylate cyclase by VIP. 

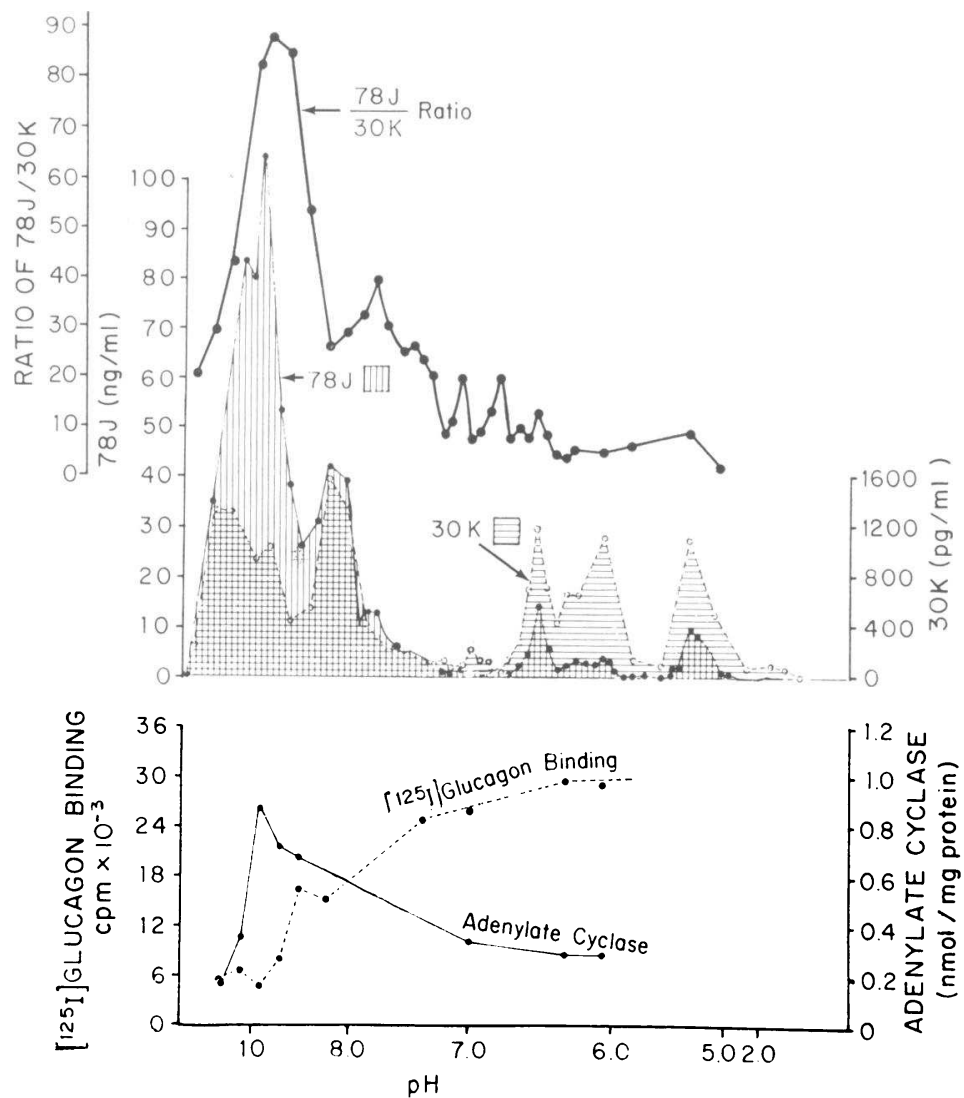

FIGURE 5 Isoelectric column chromatography of partially purified 2,900 mol wt fraction. Conventional plotting of $\mathrm{pH}$ gradient has been eliminated but instead $\mathrm{pH}$ is marked on the horizontal axis in lieu of the fraction numbers. Upper panel is the immunometric ratio of each fraction; middle panel is the glucagon-like immunoreactivity measured with antisera 78J and $30 \mathrm{~K}$; and the lower panel is the adenylate cyclase stimulating activity expressed in nmol of cyclic AMP formed per milligram rat liver membrane protein and [ $\left.{ }^{125} \mathrm{I}\right]$ glucagon displacing activity.

are the biologically active components was obtained by testing each second fraction from the isoelectric focusing column for both adenylate cyclase activation and ability to displace $\left[{ }^{125} \mathrm{I}\right]$ glucagon from partially purified rat liver membranes. As shown in the isoelectric focusing chromatogram in Fig. 4 (lower panel), displacement of $\left[{ }^{125} \mathrm{I}\right]$ glucagon and stimulation of adenylate cyclase activity were essentially confined to the fractions containing the main peak of immunoreactivity and having an immunometric ratio and $\mathrm{pI}$ similar to that of pancreatic glucagon. Similarly, fractions from the isoelectric focusing column chromatography of the 2,900 mol wt fractions were tested for adenylate cyclase stimulation and displacement of $\left[{ }^{125} \mathrm{I}\right]$ glucagon. As shown in Fig. 5 (lower panel), these activities were confined to the fractions with high $78 \mathrm{~J}$ immunoreactivity and a $\mathrm{pI}$ greater than 10 . Contamination with $3,500 \mathrm{~mol} \mathrm{wt}$ peptide is excluded by the fact that the $30 \mathrm{~K}$ immunoreactivity in those fractions was below the minimal biologically active dose (cf. Fig. 6).
Glycogenolytic activity of the 3,500 mol wt fraction. To compare their glycogenolytic activities, the isolated rat liver was perfused with the $3,500 \mathrm{~mol}$ wt immunoreactive fraction, the $2,900 \mathrm{~mol} \mathrm{wt}$ immunoreactive fraction, and with crystalline pancreatic glucagon. The perfusion of $1030 \mathrm{~K} \mathrm{ng}$ eq of the $3,500 \mathrm{~mol}$ wt fraction having a $\mathrm{pI}$ of 6.2 , the entire amount available for this purpose after isoelectric focusing, resulted in the production of $48 \mu \mathrm{M}$ of glucose per $100 \mathrm{~g}$ of rat liver. However, at the end of this experiment the liver did not respond to $20 \mathrm{ng}$ of crystalline glucagon and was, therefore, clearly hyporesponsive. Five other perfusion experiments were performed with $6.830 \mathrm{~K}$ ng eq of the 3,500 mol wt fraction obtained from ion exchange chromatography and these resulted in glucose production averaging $107 \pm 14.2 \mu \mathrm{M}$ glucose per $100 \mathrm{~g}$ of rat liver, not significantly different from the response to 10 ng of crystalline pancreatic glucagon. By contrast, 20 $78 \mathrm{~J} \mathrm{ng}$ eq of the main $2,900 \mathrm{~mol}$ wt peak gave a response of only $64 \pm 15.2 \mu \mathrm{M}$ of glucose per $100 \mathrm{~g}$, sig- 
nificantly less than the response to $10 \mathrm{ng}$ of glucagon $(P<0.001)$, and $100 \mathrm{ng}$ eq gave a response comparable to $20 \mathrm{ng}$ of glucagon. It would appear that with respect to glycogenolytic activity, the 3,500 mol wt peak resembles pancreatic glucagon, while the 2,900 mol wt peptide is considerably less active.

Insulin content of extracts. To exclude the possibility that small pieces of pancreas had been inadvertently removed with the porcine duodenum and that "duodenal glucagon" might, in fact, be of pancreatic origin, insulin was assayed in 37 individual extract samples. All but three gave zero readings and in those three only traces of insulin, ranging from 2.5 to $13 \mu \mathrm{U}$ per $\mathrm{ml}$, were present in solutions that contained from 1.3 to 9 $\mathrm{ng}$ per $\mathrm{ml}$ of $30 \mathrm{~K}$ reactive glucagon. Save for the unlikely possibility that the extraction procedure selectively destroyed insulin, these extracts can be regarded as being free of insulin and, therefore, of contamination with pancreatic glucagon. Moreover, in acid-alcohol extracts (18) of the mucosa stripped from the gastric fundus, far greater quantities of $3,500 \mathrm{~mol}$ wt immunoreactive peptide having a $78 \mathrm{~J} / 30 \mathrm{~K}$ ratio of 0.97 were found, veri-

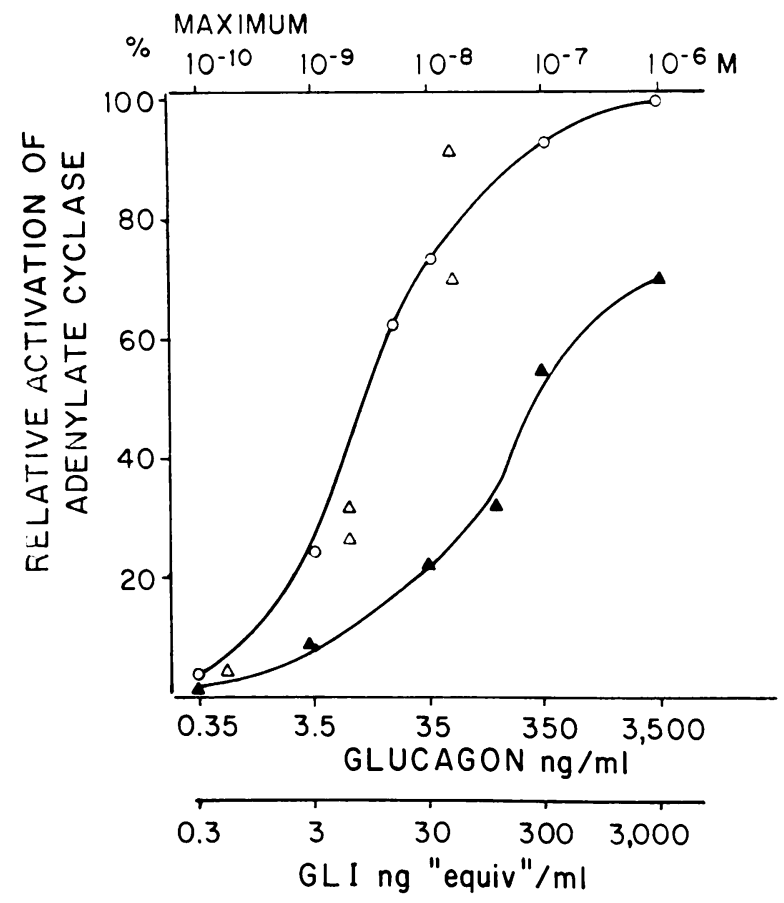

Figure 6 Comparison of adenylate cyclase activation by partially purified fractions of $3,500 \mathrm{~mol} w \mathrm{wt}$ peptide material quantitated with antiserum $30 \mathrm{~K}(\triangle), 2,900 \mathrm{~mol}$ wt peptide quantitated with antiserum $78 \mathrm{~J}(\boldsymbol{\Delta}-\boldsymbol{\Delta})$, and pancreatic glucagon $(\mathrm{O}-\mathrm{O})$. The molarity at the top refers to pancreatic glucagon. Glucagon in nanograms per milliliter refers to the partially purified fraction of gut immunoreactivity as measured with antiserum $30 \mathrm{~K}$. GLI refers to gut immunoreactivity as measured with antiserum $78 \mathrm{~J}$.
TABLE II

Comparison of $78 \mathrm{~J}$ Glucagon-Like and $30 \mathrm{~K}$ Glucagon Immunoreactivity and their Ratios in Canine Gastrointestinal Tissues

\begin{tabular}{|c|c|c|c|}
\hline & $78 \mathrm{~J}$ & $30 \mathrm{~K}$ & $\begin{array}{c}78 \mathrm{~J} / 30 \mathrm{~K} \\
\text { ratio }\end{array}$ \\
\hline & \multicolumn{3}{|c|}{$n g$ per $m g$ of protein } \\
\hline Fundus & 111.20 & 115.00 & 0.97 \\
\hline Antrum & $<0.40^{*}$ & 0.13 & $<3.0$ \\
\hline Duodenum & 5.10 & 0.92 & 5.5 \\
\hline Jejunum & 55.47 & 2.45 & 22.6 \\
\hline Ileum & 20.65 & 2.60 & 7.9 \\
\hline
\end{tabular}

* Below sensitivity of the $78 \mathrm{~J}$ immunoassay.

fying the nonpancreatic origin of a polypeptide indistinguishable from glucagon (Table II).

Morphologic evidence of extrapancreatic "true" $A$-cells. Orci et al. first reported the ultrastructural similarity between endocrine cells located in the gastrointestinal tract and the pancreatic A-cells $(6,22,23)$. It was suggested that these cells might be the site of "enteroglucagon" secretion, a prediction supported by the studies of Polak, Bloom, Coulling, and Pearse (7) in which a nonspecific antiglucagon serum was employed for immunofluorescent staining. This antiserum, which could react with both GLI-producing and glucagonproducing cells, was localized in the A-like intestinal cells (7). The suggestion that A-cells, closely resembling pancreatic A-cells, are present in the gastrointestinal tract of several mammals, including man, has been frequently made (24-28). Re-examination of these A-like cells reveals clear-cut ultrastructural differences which permit their separation into two types. One type is present primarily in the oxyntic mucosa (Fig. 7) and is indistinguishable from pancreatic A-cells (Fig. 7). The other type (Fig. 7) is most prevalent in the postduodenal intestine and is clearly differentiated by the tightly applied limiting membranes surrounding its dense granule cores $(29,30)$.

To determine if the distribution of the two types of immunoreactivity in the canine digestive tract matches the distribution of gastric true A-cells and the intestinal A-like cells, immunometric ratios of acid-alcohol extracts of gastric fundus, antrum, and the small bowel were compared. As shown in Table II, large amounts of immunoreactivity with a $78 \mathrm{~J} / 30 \mathrm{~K}$ ratio of 0.98 , the same ratio as glucagon, were found in the fundus. The ratio increased in the small intestine and rose to the high values characteristic of GLI. The distribution of immunoreactivity is therefore in accord with the morphologic predictions. Moreover, Bio-Gel P-10 filtration of canine gastric fundus reveals immunoreactivity to be predominantly in the $3,500 \mathrm{~mol}$ wt zone rather than in the 2,900 mol wt zone of enteric GLI. 

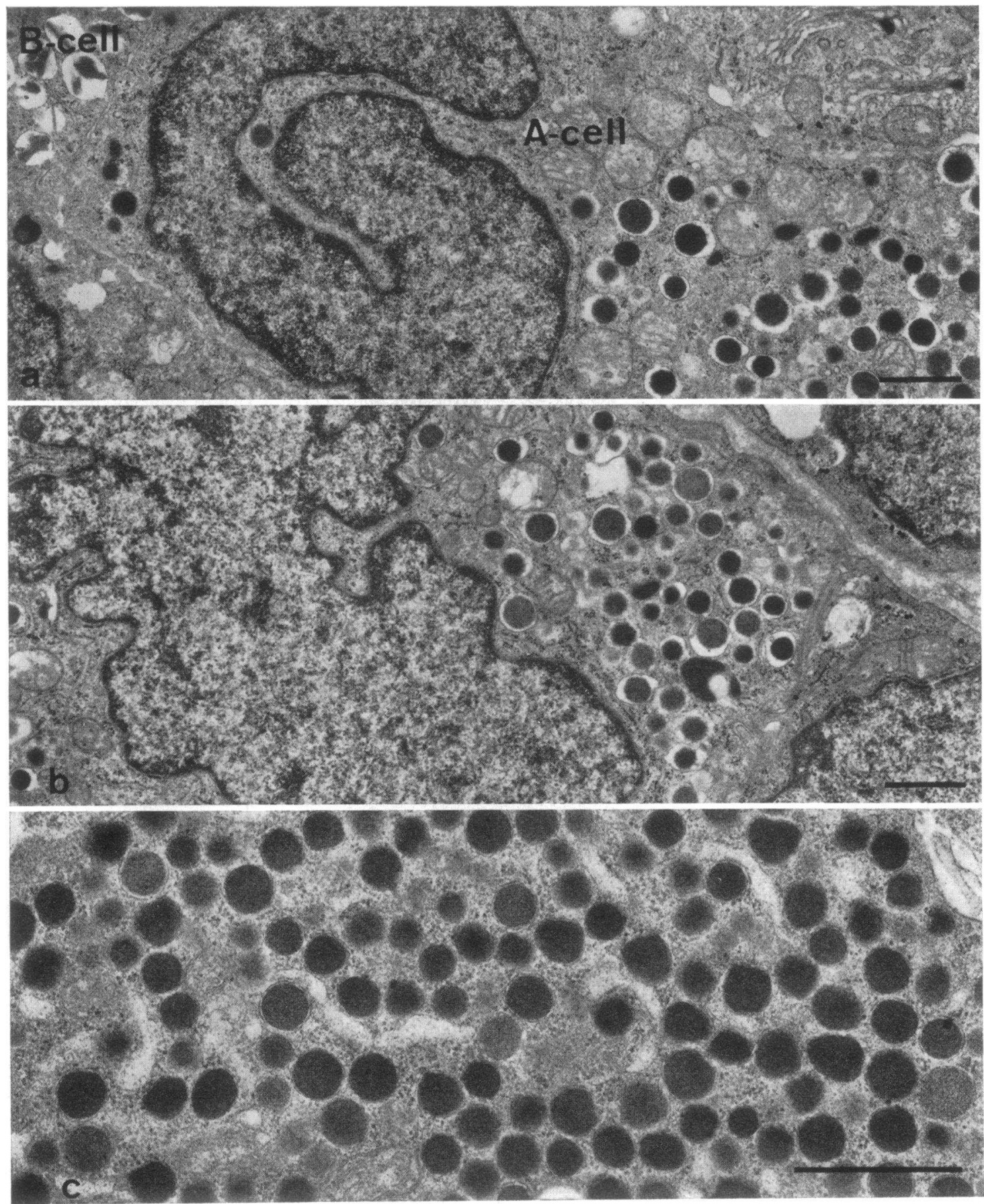

Figure 7 Comparison of pancreatic A-cell and intestinal A-cells. (a). Dog pancreatic islet. (b). Dog fundic mucosa. Note the complete morphological resemblance between the secretory granules of the pancreatic A-cell and the "true" intestinal A-cell $\times 12,500$. (c). A-like cell in the dog duodenum. Most of the secretory granules appear round. The limiting membrane is closely applied to the granule-core $\times 26,000$. The bar represents $1 \mu \mathrm{m}$.

\section{DISCUSSION}

Gel filtration of porcine duodenal extracts, as prepared by Professor Viktor Mutt, discloses two fractions which demonstrated GLI. One of these, a major 2,900 mol wt fraction, is thought to be made up largely of a polypeptide immunometrically, physicochemically, and bio- 
logically distinct from pancreatic glucagon, although sharing certain of its biologic and immunologic properties. The other quantitatively smaller 3,500 mol wt fraction could not be distinguished from pancreatic glucagon by any of the methods employed. It has a molecular weight similar to glucagon and resembles it immunometrically, giving almost identical values when assayed with specific and nonspecific antisera such as $30 \mathrm{~K}$ and $78 \mathrm{~J}$. Additionally, its behavior on disk gel electrophoresis and isoelectric focusing indicates its similarity to pancreatic glucagon with respect to net charge. Its pI of 6.2 is the same as glucagon.

The 3,500 mol wt fraction obtained after partial purification had glycogenolytic activity and adenylate cyclase activity entirely comparable to pancreatic glucagon. Moreover, adenylate cyclase activation by fractions of the $3,5000 \mathrm{~mol}$ wt material obtained by isoelectric focusing was confined to those fractions containing substantial levels of the pancreatic glucagonlike immunoreactivity (Fig. 4), indicating that it, rather than an unidentified nonimmunoreactive component, was the probable source of activity. Further evidence of the similarity between this active material and pancreatic glucagon was provided by the close relationship between displacement of [ $\left.{ }^{125} I\right]$ glucagon from liver membranes by these fractions and their immunologic and their biologic activities (Fig. 4).

Because these comparisons of physicochemical, immunometric, and biologic properties by various techniques reveal no differences between the $3,500 \mathrm{~mol} \mathrm{wt}$ gut material and pancreatic glucagon, this material may be considered indistinguishable from, if not identical to, pancreatic glucagon.

Although its source has not been established at the cellular level, these studies re-emphasized the existence of cells, most prominent in the oxyntic mucosa, that are ultrastructurally indistinguishable from pancreatic A-cells. The pattern of distribution of true A-cells matches the distribution of "true" glucagon which is present in large amounts in the fundus, is sparse in the duodenum, and virtually unmeasurable elsewhere. Thus, the original concept of Sutherland and de Duve of a gastrointestinal glucagon (31) may be correct after all. The other cell type, predominantly found in the postduodenal intestine and characterized by secretory granules with closely applied limiting membranes, could be responsible for the secretion of GLI.

Gastroduodenal glucagon may have considerable physiologic and pathophysiologic significance. In depancreatized dogs Mashiter and coworkers (3) have observed a decline in plasma levels of $30 \mathrm{~K}$ immunoreactivity $1 \mathrm{~h}$ after surgery, followed 1 and 7 days later by an increase in the arginine-stimulated rise in plasma glucagon, suggesting increased capacity for the secre- tion of extrapancreatic glucagon. Our own group has observed prompt and complete suppression of postpancreatectomy glucagon by insulin treatment and by somatostatin (5).

In view of mounting evidence that when insulin secretion is fixed or absent the level of hyperglycemia is closely related to the level of glucagon $(5,32)$, the demonstration of an extrapancreatic source of glucagon provides a unifying explanation for seemingly irreconcilable observations. First, the finding of glucagon immunoreactivity in plasma after pancreatectomy, using antiserum $30 \mathrm{~K}$, need no longer be regarded as evidence of assay nonspecificity but may indicate the presence of polypeptide identical to pancreatic glucagon. The fact that levels of extrapancreatic glucagon (1-3) increase in untreated dogs after pancreatectomy means that pancreatic diabetes, like every other form of acute and chronic experimental diabetes (33-35), and spontaneous diabetes in man (36-38) and Chinese hamsters (39) is accompanied by relative or absolute hyperglucagonemia. The only known situation in which glucagon lack and insulin lack coexist is during somatostatin administration and, in this circumstance, glucose tends to decrease rather than rise $(40)$. The likelihood that extrapancreatic glucagon, as well as pancreatic glucagon, plays an important role in the pathophysiology of diabetes has recently been proposed $(5,41-43)$.

It is proposed that the term "gastroduodenal glucagon" by applied to this polypeptide. For the postpyloric glucagon-like polypeptide, the widely used term "enteroglucagon" now seems inappropriate in view of its clear-cut differences from glucagon. "Gut GLI" or "enteroglucagonoid" would seem preferable.

As for GLI of the postpyloric bowel, it clearly differs from glucagon, not only in its smaller molecular size, but in every parameter tested. Immunometrically it is 60 times as reactive with nonspecific $78 \mathrm{~J}$ antiglucagon serum as with glucagon-specific $30 \mathrm{~K}$. In terms of charge, it is a strongly basic protein with a pI over 10.1 in contrast to glucagon with a pI of 6.2 in the system employed here. Yet, it shares with glucagon the ability to enhance glycogenolysis by stimulating adenylate cyclase activity although appearing to be far less potent on an immunometric basis using $78 \mathrm{~J}$ measurements. In the perfused rat liver, for example, $10078 \mathrm{~J} \mathrm{ng} \mathrm{eq} \mathrm{of}$ GLI are required to produce the glycogenolytic activity of $20 \mathrm{ng}$ of pancreatic glucagon, and $3078 \mathrm{~J} \mathrm{ng} \mathrm{eq}$ stimulate as much adenylate cyclase activity as $3.5 \mathrm{ng}$ of glucagon. This biologic activity is probably the result of the GLI peptide itself rather than of a nonimmunoreactive material which activates adenylate cyclase or of contaminating gastroduodenal glucagon, since correlation between $78 \mathrm{~J}$ immunoreactivity and adenylate cyclase-stimulating activity of the various 
eluates was observed. Although small amounts of $30 \mathrm{~K}$ immunoreactivity were present in these eluates, they were below stimulatory levels and were probably devoid of biological activity. The $30 \mathrm{~K}$ immunoreactivity present in the $2,900 \mathrm{~mol} w \mathrm{wt}$ eluates having a pI greater than 10 probably represents cross-reactivity with GLI. Other $30 \mathrm{~K}$ peaks in the lower $\mathrm{pH}$ zones could conceivably be biologically inactive and immunologically reactive derivatives of the $3,500 \mathrm{~mol}$ wt fraction contaminating the $2,900 \mathrm{~mol}$ wt eluates.

Whether or not GLI has its own receptor or shares with pancreatic glucagon a receptor common to both, as proposed by Battaille, Freychet, Kitabgi, and Rosselin $(44,45)$, is not settled by this study. In concentrations corresponding to those in portal plasma, GLI activates adenylate cyclase without displacing $\left[{ }^{125} \mathrm{I}\right]$ glucagon, but this could be the result of binding only to unoccupied glucagon receptors because of affinity too low to displace any of the $\left[{ }^{125} \mathrm{I}\right]$ glucagon already bound.

The issue of GLI's physiologic role is not enlightened by these studies. It does seem clear, however, that physiologic levels of GLI activate adenylate cyclase. In view of the fact that the concentration of GLI is high in the postduodenal small intestine, one might consider the possibility that it serves as an auxiliary glycogenolytic hormone required only when large quantities of glucose reach beyond the duodenum, a circumstance in which pancreatic glucagon would be maximally suppressed and insulin secretion maximally stimulated. This could prevent the excessive hepatic glycogen accumulation noted by Price, Takeshige, Max, and Voorhees in hyperalimented, gastroenterectomized, and depancreatized dogs (46) and, in addition, may serve to prevent late postprandial hypoglycemia. Indeed, a patient with dumping syndrome and reactive hypoglycemia has been reported to have low levels of GLI (47). However, others have reported high levels of GLI in reactive hypoglycemia (48), possibly a rare example of failure of the GLI secreting system to prevent this occurrence. A glycogenolytic role for GLI is supported by studies in dogs demonstrating increased glycemia associated with GLI release accompanying the absorption of large intraduodenal calcium chloride loads (49). Nevertheless, the function of GLI remains a highly speculative issue at the present time. The possibility of a role as an inhibitor of upper gastrointestinal motility also warrants consideration.

\section{ACKNOWLEDGMENTS}

This work was supported by National Institute of Health Grant AM 02700-15; Ciba-Geigy Pharmaceutical Company, Ardsley, N. Y.; Mead Johnson Center, Evansville, Ind.; Dr. Karl Thomae GmbH, Biberach an der Riss, Germany; Hoffman-LaRoche, Inc., Nutley, N. J.; Hoechst Pharmaceutical Company, Somerville, N. J.; Upjohn Company,
Kalamazoo, Mich.; Lilly Research Laboratories, Indianapolis, Ind.; and les Fonds National Suisse de la Recherche Scientifique (Grant 3.8081.72.,3.553.75).

\section{REFERENCES}

1. Vranic, M., S. Pek, and R. Kawamori. 1974. Increased "glucagon immunoreactivity" in plasma of totally depancreatized dogs. Diabetes. 23: 905-912.

2. Matsuyama, T., and P. P. Foa. 1974. Plasma glucose, insulin, pancreatic, and enteroglucagcn levels in normal and depancreatized dogs. Proc. Soc. Exp. Biol. Mcd. 147: 97-102.

3. Mashiter, K., P. E. Harding, M. Chou, G. D. Mashiter, J. Stout, D. Diamond, and J. B. Field. 1975. Persistent pancreatic glucagon but not insulin response to arginine in pancreatectomized dogs. Endocrinology. 96: 678-693.

4. Valverde, I., D. Rigopoulou, J. Marco, G. R. Faloona, and R. H. Unger. 1970. Characterization of glucagonlike immunoreactivity (GLI). Diabetes. 19: 614-623.

5. Dobbs, R., H. Sakurai, H. Sasaki, G. Faloona, I. Valverde, D. Baetens, L. Orci, and R. Unger. 1975. Glucagon: role in the hyperglycemia of diabetes mellitus. Science (Wash. D. C.). 187: 544-547.

6. Orci, L., R. Pictet, W. G. Forssman, A. E. Renold, and C. Rouiller. 1968. Structural evidence for glucagon producing cells in the intestinal mucosa of the rat. Diabetologia. 4 : 56-67.

7. Polak, J. M., S. Bloom, I. Coulling, and A. G. E. Pearse. 1971. Immunofluorescent localization of enteroglucagon cells in the gastrointestinal tract of the dog. Gut. 12: 311-318.

8. Mutt, V. 1959. Preparation of highly purified secretin. Ark. Kemi. 15: 69-72.

9. Faloona, G. R., and R. H. Unger. 1974. Glucagon. In Methods of Hormone Radioimmunoassay. B. M. Jaffe and H. R. Behrman, editors. Academic Press, Inc., New York. 317-330.

10. Yalow, R. S., and S. A. Berson. 1960. Immunoassay of endogenous plasma insulin in man. J. Clin. Invest. 39: $1157-1175$.

11. Herbert, V., K-S. Lau, C. W. Gottlieb, and S. J. Bleicher. 1965. Coated charcoal immunoassay of insulin. J. Clin. Endocrinol. Metab. 25: 1375-1384.

12. Davis, B. J. 1964. Disc Electrophoresis. II. Method and application to human serum proteins. Ann. N. Y. Acad. Sci. $121: 404-427$.

13. Reisfeld, R. A., U. J. Lewis, and D. E. Williams. 1962. Disc electrophoresis of basic proteins and peptides on polyacrylamide gels. Nature (Lond.). 195: 281-283.

14. Mortimore, G. E. 1963. Effect of insulin on release of glucose and urea by isolated rat liver. Am. J. Physiol. 204 : 699-704.

15. Salomon, Y., C. Londos, and M. Rodbell. 1974. A highly sensitive adenylate cyclase assay. Annal. Biochem. 58: 541-548.

16. Neville, D. M., Jr. 1968. Isolation of an organ specific protein antigen from cell-surface membrane of rat liver. Biochim. Biophys. Acta. 154: 540-552.

17. Rubalcava, B., and M. Rodbell. 1973. The role of acidic phospholipids in glucagon action on rat liver adenylate cyclase. J. Biol. Chem. $248:$ 3831-3837.

18. Kenny, A. J. 1955. Extractable glucagon of the human pancreas. J. Clin. Endocrinol. Metab. 15: 1089-1105.

19. Luft, J. H. 1961. Improvements in epoxy resin embedding methods. J. Biophys. Biochem. Cytol. 9: 409-414. 
20. Reynolds, E. S. 1963. The use of lead citrate at high $\mathrm{pH}$ as an electron-opaque stain in electron microscopy. J. Cell Biol. 17: 208-212.

21. Bromer, W. W. 1972. Chemical and physical properties of pancreatic glucagon. In Glucagon: Molecular Physiology, Clinical and Therapeutic Implications. P. J. Lefebvre and R. H. Unger, editors. Pergamon Press, Oxford. 27-30.

22. Orci, L., W. G. Forssmann, and R. Pictet. 1967. Mise en évidence des types de cellules a granulations denses dans le système digestif du rat. J. Microsc. 6: $74 a$.

23. Orci, L., R. Pictet, W. G. Forssmann, A. E. Renold, and C. Rouiller. 1967. Ultrastructural evidence for glucagonproducing A-cells in the gastrointestinal mucosa of the rat. 1967. Excerpta Med. Int. Congr. Ser. 213-216.

24. Orci, L., W. G. Forssmann, W. Forssmann, and C. Rouiller. 1968. Electron microscopy of the intestinal endccrine cells. Comparative study. 4th European Conference on Electron Microscopy Held in Rome in 1968. S. D. Bocciarelli, editor. Tipografia Poliglotto Vaticana, Rome. $2: 369-370$.

25. Orci, L., W. G. Forssmann, and C. Rouiller. 1969. Zur Ultrastruktur der endokrinen Zellen im Epithel des Magendarmtraktes. Verh. Anat. Ges. 125: 187-194.

26. Forssmann, W. G. 1970. Ultrastructure of hormoneproducing cells of the upper gastro-intestinal tract. In Origin, Physiology, and Pathophysiology of the Gastrointestinal Hormones. W. Creutzfeldt and F. K. Schattauer, editors. Stuttgarter Verlagskontor GmbH., Stuttgart. 31-70.

27. Solcia, E., G. Vassallo, and C. Capella. 1970. Cytology and cytochemistry of hormone-producing cells of the upper gastrointestinal tract. In Origin, Physiology, and Pathophysiology of the Gastrointestinal Hormones. W. Creutzfeldt and F. K. Schattauer, editors. Stuttgarter Verlagskontor GmbH, Stuttgart. 3-29.

28. Sasagawa, T., S. Kobayashi, and T. Fujita. 1973. Electron microscopy of human GEP endocrine cells. In Gastro-Entero-Pancreatic Endocrine System. T. Fujita, editor. Igaku Shoin Ltd., Tokyo. 31.

29. Bussolati, G., C. Capella, E. Solcia, G. Vassallo, and P. Vezzadini. 1971. Ultrastructural and immunofluorescent investigations on the secretin cell in the dog intestinal mucosa. Histochimie. 26: 218-227.

30. Solcia, E., A. G. E. Pearse, D. Grube, S. Kobayashi, G. Bussolati, W. Creutzfeldt, and W. Gepts. 1973. Revised Wiesbaden classification of gut endocrine cells. Rendic. Gastroenterol. 5 : 13-15.

31. Sutherland, W. W., and C. V. de Duve. 1948. Origin and distribution of the hyperglycemic-glycogenolytic factor of the pancreas. J. Clin. Invest. 27: 663-674.

32. Sakurai, H., R. Dobbs, and R. H. Unger. 1974. Somatostatin-induced changes in insulin and glucagon secretion in normal and diabetic dogs. J. Clin. Invest. 54: 13951401.

33. Müller, W. A., G. R. Faloona, and R. H. Unger. 1971. The effect of experimental insulin deficiency on glucagon secretion. J. Clin. Invest. 50: 1992-1999.

34. Katsilambros, N., Y. A. Rahman, M. Minz, R. Füssganger, K. E. Schroder, K. Straub, and E. F. Pfeiffer.
1970. Action of streptozotocin on insulin and glucagon response of rat islets. Horm. Metab. Res. 2: 268-270.

35. Braaten, J. T., G. R. Faloona, and R. H. Unger. 1974. The effect of insulin on the alpha-cell response to hyperglycemia in long-standing alloxan diabetes. J. Clin. Invest. 53: 1017-1021.

36. Aguilar-Parada, E., A. M. Eisentraut, and R. H. Unger. 1969. Pancreatic glucagon secretion in normal and diabetic subjects. Am. J. Med. Sci. 257: 415-419.

37. Unger, R. H., E. Aguilar-Parada, W. A. Müller, and A. M. Eisentraut. 1970. Studies of pancreatic alpha cell function in normal and diabetic subjects. J. Clin. Invest. $49: 837-848$.

38. Müller, W. A., G. R. Faloona, E. Aguilar-Parada, and R. H. Unger. 1970. Abnormal alpha-cell function in diabetes. Response to carbohydrate and protein ingestion. N. Engl. J. Med. 283: 109-115.

39. Frankel, B. J., J. E. Gerich, R. Hagura, R. E. Fanska, G. C. Gerritsen, and G. M. Grodsky. 1974. Abnormal secretion of insulin and glucagon by the in vitro perfused pancreas of the genetically diabetic Chinese hamster. J. Clin. Invest. 53: 1637-1646.

40. Alberti, K. G., N. J. Christensen, S. E. Christensen, A. P. Hansen, J. Iversen, K. Lundbaek, K. Seyer-Hansen, and H. Orskov. 1973. Inhibition of insulin secretion by somatostatin. Lancet. 2: 1299-1301.

41. Unger, R. H., and L. Orci. 1975. The essential role of glucagon in the pathogenesis of diabetes mellitus. Lancet. 1: $14-16$.

42. Sakurai, H., R. Dobbs, and R. H. Unger. 1975. The role of glucagon in the pathogenesis of the endogenous hyperglycemia of diabetes. Mctab. (Clin. Exp.). In press.

43. Muñoz, L., E. Blazquez, and R. Unger. 1975. Gastric $\alpha$-cell function in normal and diabetic dogs. Diabetes. In press.

44. Battaille, D. P., P. Freychet, P. E. Kitabgi, and G. E. Rosselin. 1973. Gut glucagon: a common receptor site with pancreatic glucagon in liver cell plasma membranes. FEBS (Fed. Eur. Biochcm. Soc.) Lett. 30: 215-218.

45. Battaille, D., P. Freychet, and G. Rosselin. 1974. Interactions of glucagon, gut glucagon, vasoactive intestinal polypeptide, and secretin with liver and fat cell plasma membranes: binding to specific sites and stimulation of adenylate cyclase. Endocrinology. 95: 713-721.

46. Price, J. B., Jr., K. Takeshige, M. M. Max, and A. B. Voorhees, Jr. 1972. Glucagon as the portal factor modifying hepatic regeneration. Surgery (St. Louis). 72: 74-82.

47. Lawrence, A. M. 1972. Pancreatic alpha-cell function in miscellaneous clinical disorders. In Glucagon Molecular Physiology, Clinical and Therapeutic Implications. P. J. Lefebvre and R. H. Unger, editors. Pergamon Press Inc., Elmsford, N. Y. 259-274.

48. Rehfeld, J. F., and L. G. Heding. 1970. Increased release of gut glucagon in reactive hypoglycaemia. $\mathrm{Br}$. Med. J. 2: 706-707.

49. Böttger, I., G. R. Faloona, and R. H. Unger. 1972. The effect of calcium and other salts upon the release of glucagon-like immunoreactivity from the gut. J. Clin. Invcst. $51: 831-836$. 